\title{
A Critical Study of Objections of Orientalists and Hadith-Deniers on Sense-Reporting of Hadith Text \\ "Hafiz Rizwan Abdullah \\ ${ }^{* * *}$ Dr. Iftikhar Ahmed
}

\section{ABSTRACT:}

Riwayat bil-ma'na (sense-reporting) means that a narrator narrates a hadith in his own words without uttering the actual words he listened. It is a method of narrating hadith which is, although opposed by some scholars and declared an illegal and unfair method, yet most of hadith-experts have conditionally allowed it. A narrator may not be allowed to report the sense/meaning of a hadith without abiding by some condi-tions. It is a fact that, on basis of sense-reporting, many orientalists have played the blame game on hadith. After having influenced by the orientalists, hadith-deniers, modernists and many so-called Muslim scholars have also made objections on this ground. The main reason of these objections, in their opinion, is that during the whole period before compilation of hadith, hadith narrating has been used to take place by the method of sense-reporting. It is a recognized fact that all people do not have the same level of reasoning, memorizing and understanding capability. It is not possible that ten people narrate the words of Prophet in the same wording. That's why there are many narrations of Hadith on the same topic and different as well. This difference means that any change or fluctuation has been occurred in hadiths. So, these hadiths will no more be viable argument. Moreover all hadiths of books of hadith comprise sense-reporting. The deniers of hadith propagate such ambiguities and make denial and disregard of hadith. So, it is needed to review the objections of deniers of hadith on research point of view and to describe the conditions of hadith-experts clearly. Not mentioning these conditions is, no doubt, dishonesty. Besides this, it is to view different forms of sensereporting which are present in hadith. So that the matter being discussed, may be made clear on all its aspects. This research article consists on this discussion.

Keywords: riwayat bil-ma'na, sense-reporting, hadith-deniers, orientalists.

No doubt, Hadith is second basic source of Islamic Sharia. Due to its importance, ancient and modern scholars took special interest in it. They compiled it, wrote books on hadith informants, set up the art of explanation and differentiating hadith. They laid the foundation of many other sciences and arts concerning hadith. A basic reason of interest and struggle of Muslim scholars in serving hadith was that it is the second basic source of Sharia and a commentary on Quran and that it is a preserver of Islamic civilization and its social values. It is the Hadith which highlights the rules, regulations and limitations of Islamic society. Due to this much importance of hadith, it has always been a thorn in eyes of the enemies of Islam. So, they have always been making it

"Ph.D Scholar, Lecturer Islamic Studies, Govt. Post Graduate College, Khanewal. Email: rizwan.alhafiz89@gmail.com

*** Chairman Department of Islamic Studies, The Islamia University of Bahawalpur. 
the target of their criticism so that the righteousness and certification status of hadith should be made suspicious, and position of Islamic society rather Islamic sharia should be disturbed. Such people had also been present in first centuries, who challenged the deciding position of hadith. Imam Shafei, other jurists and hadith-experts chased their ideologies and defended hadith on solid academic basis. In $20^{\text {th }}$ century, the enemies of Islam continued their practice with their modern name 'orientalists'. They criticized and raised objections upon different aspects of Islam but they couldn't succeed to get the required consequences. So, they turned the direction of their objections towards hadith and the biography of the Prophet Ignaz Goldziher earned fame on objections upon hadith. Among his objections on hadith, there are the objections on sense-reporting as well. These objections, in deed, were the result of his objections on compilation of hadith. He thought that compilation of hadith couldn't take place till two and half centuries, rather it was used to be reported people to people orally. So, in so much long period the original wording of Apostle could not maintain its originality. Sensereporting was a common practice among hadith-experts as well. That's why every narrator of hadith was supposed to narrate the hadith in his own words. So, narrations presented in books of hadith are not the wording of Prophet narrators. As the narrators got the hadith, they reported it in their own words. Due to this practice, the validity of hadith was shaken. For an instance, a renowned orientalist Ignaz Goldziher writes in his book:

"The question whether transmitted accurately in substance but not in wording may claim to be a correct hadith (riwaya bi'l-ma'na) a question which was raised as early as the third century becomes increasingly a real problem for the science of tradition." Influenced by such type of orientalists, some Muslim scholars also raised this objection. As these scholars were Muslims, so their thoughts affected the society bit more than the orientalists and influenced a large part of community. For example an Egyptian scholar Mufti Muhammad Abduhoo and his followers expressed objection on the hadiths containing sense-reporting. ${ }^{2}$ In Sub-Continent a specific group was formed which was named Ahl-e-Qur'an. Actually this was the group of hadith-deniers in disguise of Ahl-e-Qur'an. They influenced a great part of higher Muslim community. Among them was a remarkable name, Ghulam Ahmad Pervez. Making objection on sense-reporting, he writes:

"As many books of hadith (including Bukhari, Muslim) we own, none of their hadiths may be claimed to be the exact words of Prophet All hadiths comprise sensereporting. Their style is, that a companion (Sahabi) heard something from Prophet, whatever he understood about the said wording of Prophet, he reported forward in his own words. And so on this process continued up to two and half centuries. After that, people collected this type of spread things. So, it is obvious that how much it will be connected with the actual words of Prophet

According to Ghulam Ahmad Pervez, due to this sense-reporting, following results are extracted:

All hadiths are depending on sense-reporting. 
- $\quad$ None of Hadith books may be claimed that its hadiths are the exact words of Prophet

- Among the sense-reporters, were such type of informants as well, who were not capable of understanding the real concept.

- $\quad$ All narrators practiced sense-reporting.

Moreover, the modernists also contributed in this job. For example a scholar of Ghamidi school of thought, Sajid Hameed expresses his notions in such a way:

"I had made title of my article 'Matn-e-Hadith me Hamare Tasarrufa't'. The word 'tasarruf' means mattering, scuffling, utilizing etc."

Moreover, he writes: "A remarkable part of hadiths has been transferred in sensereporting methodology. Whenever a prudent, after making it clear from a prudent, transmits a thing in his own words, he is not transmitting the concept of his informant, but that of his own. It is a natural requirement of reporting, because before compilation of hadith, hadiths were rarely reported as a complete hadith rather these were stated in light of informant's own opinion or practice. In such type of conversation, transforming of concepts is a natural matter. In first ages, hadith texts were not in written form, from which words of text might be verified. This facility was achieved after the hadith books came into existence. Now these books consist upon the hadiths of sense-reporting. Transferring of hadiths by sense-reporting, concepts are so changed and they do not let the real thing remain universally compatible and free of errors whereas Allah and His Apostle has issued universal and errorless commandments."4

He further writes: "In modern age, among the reasons of attack on hadith, there is a reason that when the prudent and non-prudent reporters converted hadith in their own words, concept was differed on minor or major basis."

According to Ghamidi school of thought, Muslim scholars have worked out in hadith. As hadiths had not been written, so there was no source to verify them. Due to sensereporting, concept and subject of hadith varied. It is needed to work on the collection of hadiths from the beginning, so that it would be investigated that which words are actually of Prophet and which were added by the informants afterwards.

These are the major objections which were raised on sense-reporting by orientalists and the hadith-deniers. Their main target is to prove that traditions narrated in books of hadith are actually not the teachings of Prophets but that of narrators. Those may be right, may be wrong as well. So those are not trustworthy. In the same way, hadithexperts deceived Ummah, saying that those are the words of Prophet䔝, whereas those are not. The experts didn't make clarity about this reality, unless Ummah may lose the trust in hadith. In the following lines, we will analyze these objections in perspective of rule set by hadith-experts, so that their contribution and services for hadith and their dignity would be highlighted and the reality of these objections may be exposed as well. Terminology of Sense-Reporting (Riwayat bil-ma'na):

In sense-reporting, a narrator describes the tradition in his own words instead of its exact wording. Hafiz Ibn-us-Salah writes: 


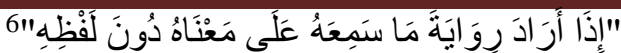

"When a narrator describes the meanings of a tradition instead of its exact wording, it will be sense-reporting."

Status of Sense-Reporting:

The rule of narrating a hadith was to report it in its original words as Prophet uttered. However, sense-reporting was allowed when it was severely needed. This permission was not a general rule, rather it was an exceptional situation. But orientalists tried to bring it under discussion as a general rule. If a narrator had to narrate a hadith as sense-reporting, after narrating, he was demanded to explain it in such words which mentioned that those were not the words of Prophet, but those were the words of the narrator. The companions (Sahaba) followed the same methodology. They had the utmost desire to narrate a hadith within the words they had listened from the Prophet as Umar bin Khattab describes:

$$
\text { "من سمع حديثا فحدث به كما سمع فقد سلم-"7 }
$$

"Whoever listened a hadith and narrated it as listened, he remained safe."

Explaining this, Allama Suyuti wrote:

"وينبغي للراوي بالمعنى أن يقول عقيبه أو كما قال أو نحوه أو شبهه او ما أثبه هذا من الألفاظ، وقد كان

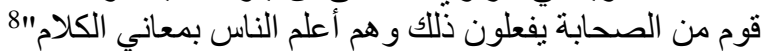

"A sense-reporter should use to utter the words like شبهاني ,نحوه بكما قال them, because Sahaba used to follow the same practice, whereas they were the most aware of the concept."

So, it is very clear that the actual rule of narrating hadith, near hadith-experts was to narrate word by word, not that of sense-reporting. Sense-reporting was just allowed in some special situations. And this permission was not granted to all the narrators as Ghulam Ahmad Pervez and other hadith deniers attempted to prove. All hadithexperts and jurisprudents agree that the permission was only for the person who had the best approach and knowledge of the words and their reasoning. Other than such a person was not permitted for sense-reporting. Hafiz Ibn-us-Salah describes:

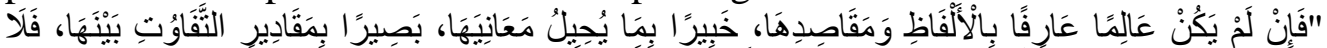

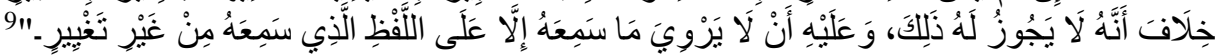
"If a narrator has no knowledge of the words and their objectives and he is unaware of variations of the words, sense-reporting is not lawful for him. It is necessary for him to narrate a hadith with the words he heard."

Allama Aamdi writes:

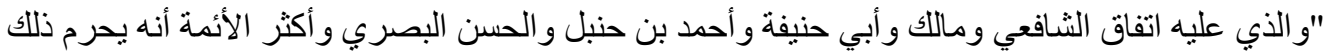

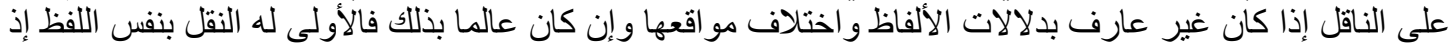

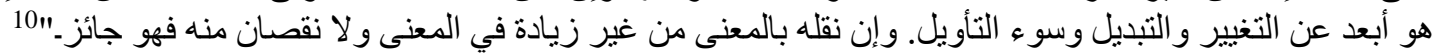

"The opinion on which Imam Shafie, Malik, Abu Hanifa, Hassan Basari and most of the imams agree, is that the narrator having no awareness of words-management and about the difference of situations, sense-reporting is strictly forbidden for him. If he has the knowledge of words-management, it would be better for him to abide by the 
words because it is safer than the changing of the wording. However, if he makes sense-reporting in such a way that meanings are not fluctuated, it is lawful."

Allama Ibn-e-Kathir says:

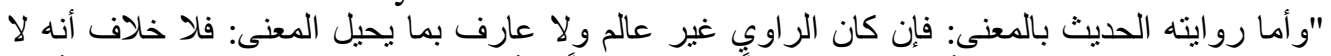

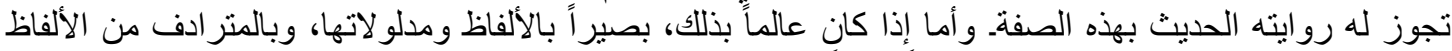

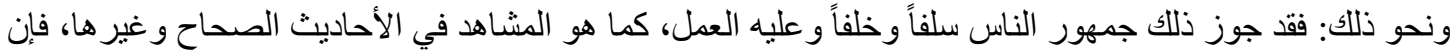

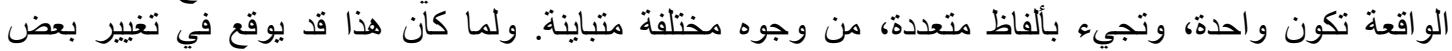

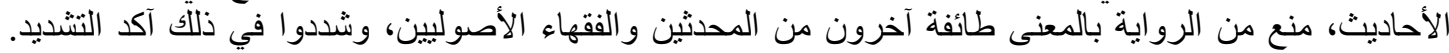

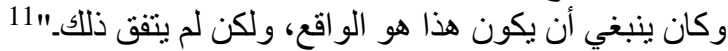
"As for as the sense-reporting is concerned, if the narrator is unaware of the things which change the meanings, no one disagree on unlawfulness of sense-reporting. And if he is aware of these things and bears the insight of words-management and is aware of substitutes of the words, most of the experts have declared sense-reporting lawful for him and the same has been practiced. In the authentic hadiths, the same matter is obvious. So, we observe that the same incident is being reported in different words. As the sense-reporting may cause the change in hadith, so some hadith-experts and jurisprudents have strictly prohibited this practice. Righteously it must be so, but it could not be agreed."

It is absolutely clear by above mentioned theories of hadith-experts that near them, it was a recognized rule a hadith should be narrated in the words uttered by Prophetw. However in some specific circumstances, sense-reporting was allowed. This permission was only for those narrators who had complete knowledge of words management and had been well aware of vocabulary and Sharia. Their sense-reporting must not fluctuate the theme and order of the hadith. Orientalists and hadith-deniers try to conceal the facts by ignoring these things and show as all hadiths are sense-reported. They claim that no hadith exists which would comprise the original words of Prophet. Moreover, all hadith-narrators used to utilize sense-reporting and made changes in hadiths.

Hadith-deniers rightly say that a mistake may occur by a person. It is possible that a narrator may have narrated a hadith in his own words, according to his knowledge. And, while narrating, he would have chosen such words whose meanings were opposite to the purpose of Prophet But this kind of objection would be valid if the experts would have not mentioned such traditions and their reasoning. Indeed, if a narrator committed any mistake in sense-reporting, hadith-experts clearly mentioned it. For this, hadith-experts wrote comprehensive books on Ilal-ul-Hadith (hidden setbacks of hadith). This art is the most difficult task. For it, a high level of memory, knowledge and minute insight is required. That's why there are very few experts in this field, like Ibn-e-Madini, Ahmad, Bukhari, Abu Hatim and Darqutni. After studying their books, nobody can claim that the narrators had made changes in hadiths and had changed their original meanings in accordance with their temperament, sect attachment and political ideologies. If a narrator committed any mistake, consciously or unconsciously, while narrating a hadith, the experts chased that mistake. Its few examples may be seen in 'Sharah Ilal Altirmidi' of Allama Ibn-e-Rajab. ${ }^{12}$ So, 
claiming that due to sense-reporting, hadith has lost its originality and has become unreliable, is a scientific dishonesty and overlooking the facts.

Opinions of Experts about Legitimacy and Illegitimacy of Sense-Reporting:

The objectors say that sense-reporting was generally allowed and it was a recognized rule of hadith-experts due to which the words of traditions lost their originality. Whereas the fact is that there remained disagreement among the experts and jurisprudents on legitimacy of sense-reporting. So, some of them have totally forbidden the sense-reporting, and some agree on its legitimacy.

1. A group of experts and jurisprudents has completely prohibited the sensereporting. This group consists of the personalities like Abdullah bin Umar, Qasim bin Muhammad, Muhammad bin Sireen, Raja bin Heva, Sufyan bin Uyaina, Abd-ulWaris, Yazid bin Zuray, Wohaib, Yahya bin Mueen, Abu Bakr Razi. ${ }^{13}$

So, the above mentioned experts, jurisprudents and their followers have absolutely forbidden the sense-reporting. It means that the hadiths narrated by them comprise the words uttered by the Prophet噛.

2. A major group of the most of hadith-experts and jurisprudents has declared the sense-reporting legal. The four Imams are also included in this group. They impose the ultimate trust in performing the meanings of hadith. Explaining it, Hafiz Ibn-usSalah writes:

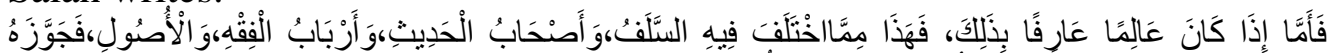

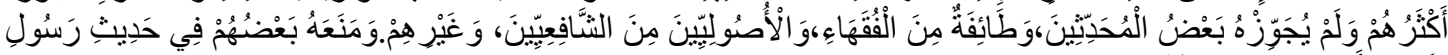

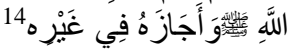
"If a narrator has awareness of objectives and variations of the words, hadith-experts and jurisprudents are divided regarding the sense-reporting. Majority has declared it legal, whereas a group of some experts and Shafi'ee jurisprudents has declared it illegal. And some claim that it is prohibited in hadith of Prophet and allowed while narrating the sayings of others."

Allama Ibn-e-Rajab writes:

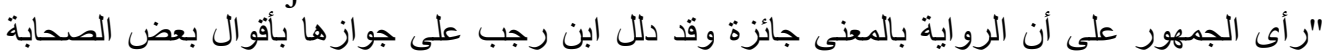

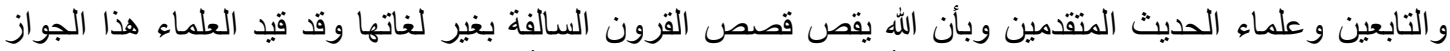

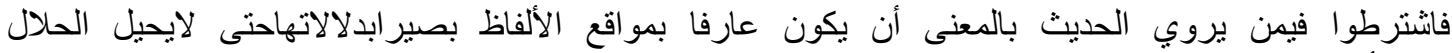
حر امأويضع الداليل في غيرمكانه."

"Opinion of majority is that sense-reporting is lawful. Ibn-e-Rajab provided arguments on its lawfulness. Among them sayings of Sahaba and Tabi'een, former hadith-experts and Allah's practice of describing the stories of ancient societies in other than their native language. The scholars have imposed some conditions that in this way of narration, the narrator must be aware of the situational usage and reasoning of the words. Nevertheless he would make the lawful thing unlawful and place the reason wrongly."

\section{Conditional Permission:}

Although most of the scholars, hadith-experts, jurisprudents and the fundamentalists declare the sense-reporting lawful, yet it was not a general permission. Each narrator 
was not supposed to take the benefit from this permission, there were some conditions and limitations for it, without complying them, sense-reporting was not allowed. Explaining this, Ibn-us-Salah writes:

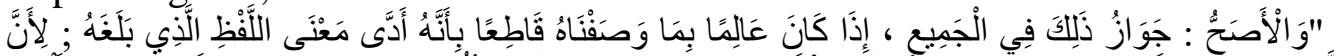

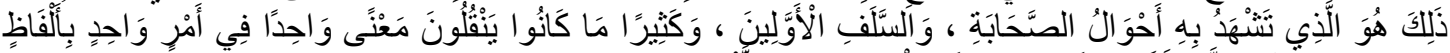

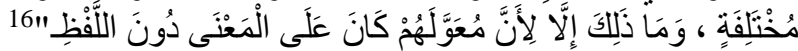

"The most reasonable thing is that sense-reporting is lawful in all situations. If a narrator is a scholar, as we have described; he must be sure that he has conveyed the accurate sense of the word that he learnt. This is the situation on which the practice of Sahaba and first predecessors witness. Most of them used to present the meanings in different words, because they had trust in the meaning instead of the word."

Among the personalities who had talked about the conditional permission of sensereporting are Imam Ghazali ${ }^{17}$, Imam Tirmidi ${ }^{18}$, Allama Aamdi ${ }^{19}$, Hafiz Ibn-e-Hajr Asqalani ${ }^{20}$, Imam Ibn-e-Hazm ${ }^{21}$, Imam Razi ${ }^{22}$ etc.

The above discussion shows that the original narration of traditions is the word to word narration. Sense-reporting is a branch of narration that is conditionally allowed by some scholars. So, the saying of orientalists that sense-reporting is a general rule of hadith narration, is against the scientific facts.

\section{The Conditions for Sense-Reporting:}

There are some important conditions phrased by the scholars for sense-reporting, in the following:

The narrator must be a scholar of reasoning and minutes of words and their meanings ${ }^{23}$. Hadith should not be concerning the worship matters, like Takbeer, Salah, Tash'hud, Aqamah etc ${ }^{24}$. Hadith should not be related to the Jawame-ulkalim $^{25}$. If hadith comprises Sharia meanings, the narrator should have the knowledge of Sharia ${ }^{26}$. The narrator must be competent in his religion, true in his wording and must be well aware of what he is describing. The narrator must have complete knowledge of Arabic language and its addressing methods. The narrator must be having the insight of meanings and jurisprudence. The narrator must be aware of all those matters due to those change occurs in meanings and of the matters due to those change does not occur. After narrating the hadith, he should utter the words of قال، نحوه يا شبر. The narrator must explain while sense-reporting, that this is the meaning of Prophet's saying, not his words. ${ }^{27}$

There are several more conditions except the conditions mentioned above. Allama AlJaza'iri has discussed them in detail ${ }^{28}$. Hafiz Ibn-e-Rajab writes:

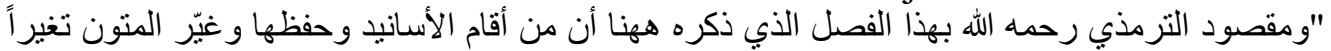

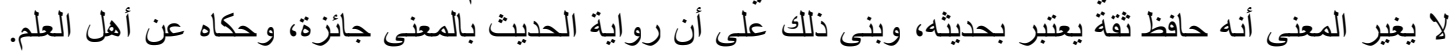

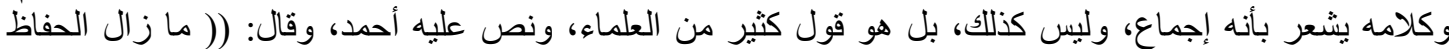

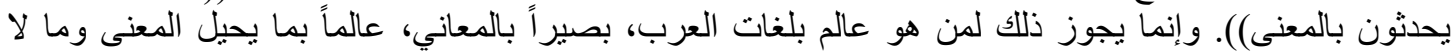

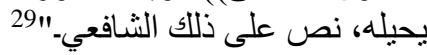

"The chapter which Imam Tirmidi has mentioned here, is for that which maintained the chain of the narrators and learnt it by heart but didn't make such a change in the 
text that would change the meanings, such a person is preserver (hafiz) and competent. The hadith narrated by such a person can be used for reasoning. He has laid its foundation on the thing that sense-reporting is lawful, and he has copied it from the knowledgeable personalities. We come to know by it that there is consensus upon it, whereas it is not so. It is the opinion of most of the scholars, and Imam Ahmad has declared that the huffaz of hadith have been making sense-reporting. But this is permitted only to the person who would be a scholar of Arabic dictionaries, having the insight of meanings and having been aware of utilization and nonutilization of meanings. Imam Shaf'ie has declared it."

Allama Abd-ul-Ali Muhammad bin Nizam-ud-Din has discussed this matter on a different angle, he explains:

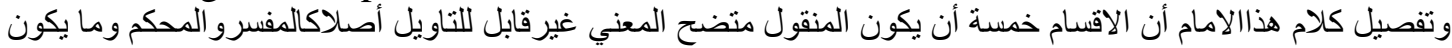

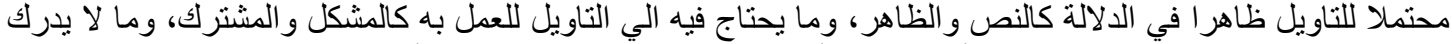

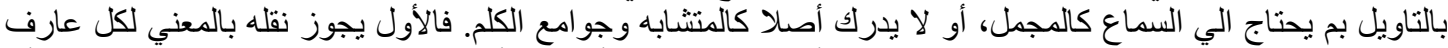

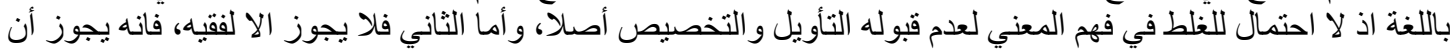

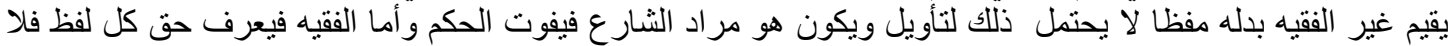

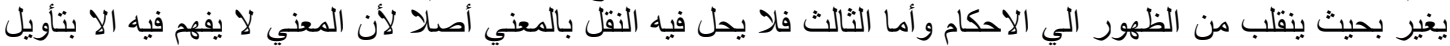

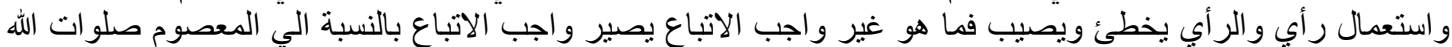

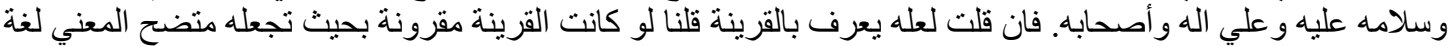

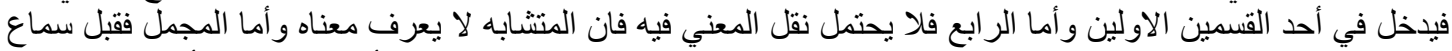

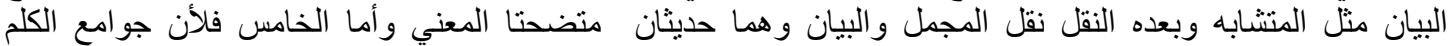

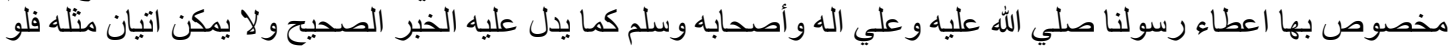

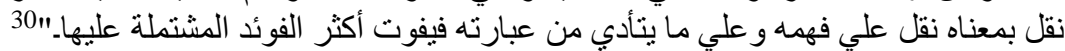

"There are five types of traditions; 1) Meanings of the narrated matter must be very clear and must not be originally able to be interpreted, as mufassar and muhkam 2) The type in which there would be probability of interpretation and whose reasoning would be obvious, as nass and zahir 3) The type the interpret-tation might be needed to act upon them, just as a mushkil and mushtarak. 4) The type that would not be able to understand through interpretation, rather hearing would be needed as mutashabih. 5) Jawame-ul-Kalim. First type of sense-reporting is lawful for the person who is expert in Arabic language. As it doesn't need the interpretation, so there is no probability in understanding its meanings. The second type of sense-reporting is lawful only for jurisprudent. May be other than a jurisprudent would use such an alternate word that would not fulfil the purpose of Prophet As for as the jurisprudent is concerned, he recognizes the place of the word. So, he will not make such a change which would change the obvious order. Third type of sense-reporting is absolutely not lawful because its meanings cannot be understood without utilizing the interpre-tation and opinion of its meanings, because there is possibility of mistake in opinion. Thus a thing which is not obligatory to follow, may become obligatory. If you say that it would be understood by the methodology, we'll say that if the methodology clears the meanings literally, then it would come under the first two types. In fourth type, there is no probability of sense-reporting because meanings of the similar words are not understood and opposite also seems to be like the similar before hearing the description. As 
for as the fifth type is concerned, sense-reporting is also not lawful because according to a correct and authentic hadith 'Jawame-ul-Kilim are specified with the Prophet So such words may not be brought. The sense-reporting will be in accordance with the narrator's understanding and performing style of meanings of the words. So, a major part of these benefits would be spoiled on which that hadith comprises."

Tahir Aljazairi has described three following conditions in his book:

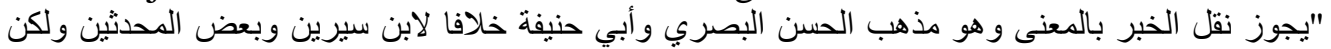

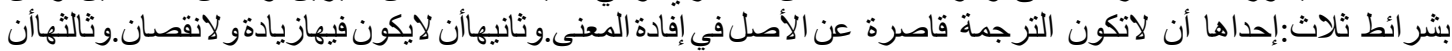

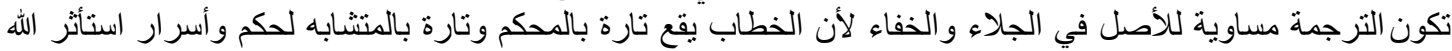

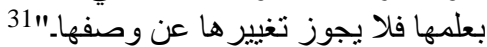

"Unlike Imam Ibn-e-Saireen and some other hadith-experts, Imam Hassan Basri and Imam Abu Hanifah's thought is that sense-reporting is lawful. There are three following conditions:

1. The translation should not be unable to transmit the meanings of the wording.

2. There should be no fluctuation in it.

3. The translation should be equal to the original as per the inner and outer of the wording because while addressing the order is either described as final orders or as similarities. Or there are mysteries of Almighty Allah which are kept by Allah for His own knowledge. So their description may not be changed."

These are the conditions which are imposed by the scholars and experts of different juristic schools of thought. Keeping in view these conditions, if sense-reporting of hadith is allowed, it is hard to imagine any change or distortion in the meanings of hadith. On this, Dr. Muhammad Abu Shabhah writes:

اذا علمنا كل ذلك أيقا أن الرواية بالمعني لم تجن علي الدين، و أنها لم تدخل علي النصوص التحريف و التبديل كما زعم بعض المستشرقين ومن لف لفهم، وأن الله الذي تكفل بحفظ كتابه قد تكفل بحفظ سنة نبيه من التحريف ولن والتبديل،

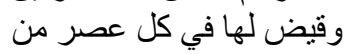
ينفون عنها تحريف الغالين وانتحال المبطلين، وتأويل الجاهلين، فذهب الباطل الدخيل، وبقي الحق موردا صافيا اللشاربين.32

"When we had known all the things, so we were sure that sense-reporting had neither made loss to Din nor made any changes in its ultimate texts as orientalists and their followers think. As Allah has Himself taken the responsibility of the security of His Book, in the same way He has taken the responsibility of keeping the Sunnah of His Prophet secure from any kind of distortion and changing. For this purpose, He appointed such people in every age who defended the Sunnah from all distorters, the false sects and the interpretations of ignorant people. So the false went away and the right was remained for its seekers."

Another important aspect is that the whole discussion on sense-reporting is about age before the compilation of hadith. When hadiths were compiled and the books were arranged, taking care of the words got necessary. Sense-reporting may be made during the public speeches and while preaching but while reasoning and approaching the origin, narrating word to word is compulsory. ${ }^{33}$ Hafiz Ibn-us-Salah writes: 


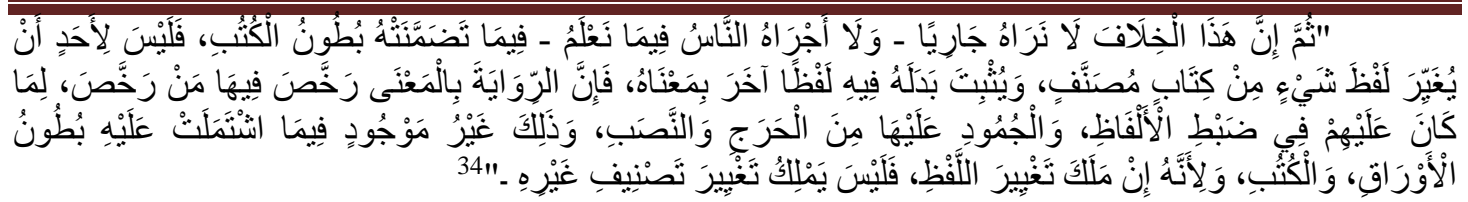

"It should be kept in mind that we don't think that the disagreement is no more continued. And as for our knowledge in hadith books this disagreement about hadiths is no more continued. So, it is not lawful for anyone to make changes or to add substitutes of the words in the words of hadith of published books. Whoever allowed the sense-reporting, it was given to him who had the ability to learn by heart and to preserve it. It is no problem now because the words are preserved on pages and in books. If someone attempts to change the words, he will not be able to change the whole book. So, now there is no capacity of sense-reporting."

\section{Conclusion:}

It is now very clear after the above detailed discussion on sense-reporting that the actual rule of narrating hadiths near hadith-experts was that it should be narrated with its original words uttered by the Prophet. However the exceptional situation of sense reporting exists which is allowed in some specific circumstances. This permission was not for all the narrators. Although some hadith-experts have absolutely declared the sense-reporting unlawful, yet most of the jurisprudents and hadith-experts allowed it under some hard conditions. If sense-reporting is made, keeping these conditions in view, there is no problem near the experts. The reason behind this 'no problem' is that this permission was limited and conditional. And secondly the conditions were so hard to make any problem with the hadith. Despite of this, if somebody makes reasoning of being hadiths uncertified due to sense-reporting, how can it be declared the scientific honesty?

\section{References:}

${ }^{1}$ Golziher, Ignaz, Muslim Studies (Albany, State University of New York Press, 1971)187/2.

2 Toufique Sidqui, Dr., Al-Islam Huwa Al-Qur'an Wahdahu, Al-Minar Magazine, February 1906AD,913/9.

${ }^{3}$ Ghulam Ahmad Pervez, Shakhsiat Prasti, Tulu-e-Islam Magazine, October 1949AD, 29/10.

4 Sajid Hameed, Matn-e-Hadith main Hamaray Tasarrufa't (2), Ishra'q Lahore, Feb.2017AD, 48$52 / 29$.

5 Ibid p.69.

${ }^{6}$ Ibn-us-Salah, Othman bin Abd-ur-Rehman, Muqaddamah Ibn-us-Salah fi Uloom-ul-Hadith (Beirut, Dar-ul-Fikr Al-Ma'asir, 1986) p.213.

${ }^{7}$ Ramharmzi, Hassan bin Abd-ur-Rahman, Al-Muhaddas Al-Faasil Baina-al-Rawi wal Wa'ei (Beirut, Dar-ul-Fikr, $3^{\text {rd }}$ ed. 1404AH) p.538

${ }^{8}$ Suyuti, Abd-ur-Rahman bin Abi Bakr, Tadreeb-ur-Rawai fi Sharah Taqreeb-un-Nawawi (Riyadh, Maktaba Al-Riyadh Al-Hadithah) 102/2.

${ }^{9}$ Ibn-us-Salah, Muqaddima Ibn-us-Salah, p.213.

${ }^{10}$ Aamdi, Ali bin Muhammad, AlAhkam fi Usool Al-Ahkam, Beirut,Dar-ul-Kutub, $1^{\text {st }}$ ed.115/2

${ }^{11}$ Ibn-e-Kathir, Ismail bin Umar bin Kathir, Al-Ba'is Al-Hathith fi Ikhtisar Uloom-ul-Hadith, p.141.

${ }^{12}$ Ibn-e-Rajab Al-Hanbly, Abd-ur-Rahman bin Ahmad, Sharah Ilal Al-Tirmidi (Riyadh, Maktabah AlRushd, $2^{\text {nd }}$ ed. 2001)115-117/1. 
13 Tayyabi, Hassan bin Abdullah, Alkhulasah fi Uloom-ul-Hadith, Research: Subhi Al-Samrei (Baghdad, Al-Irshad Publications, 1971)p.116

${ }^{14}$ Ibn-us-Salah, Muqaddimah Ibn-us-Salah, p. 214

${ }^{15}$ Ibn-e-Rajab Hanbli, Sharah Ilal Al-Tirmidi, 115/1.

${ }^{16}$ Ibn-us-Salah, Muqaddimah Ibn-us-Salah, p. 214

${ }^{17}$ Ghazali, Abu Hamid, Muhammad bin Muhammad, Al-Mustasfa min Ilm-ul-Usool (Egypt, Ameeria Publications, $1^{\text {st }}$ ed. 1324AH)168/1

${ }^{18}$ Sharah Ilal Al-Tirmidi, 145/1

${ }^{19}$ Asmdi, Al-Ahkam, 115/2

20 Ibn-e-Hajr Asqalani, Ahmad bin Ali, Nuzhat-un-Nazar fi Touzeeh Nukhba-tul-Fikr (Damasks, Maktabh Al-Sabah, 1992) p.94

${ }^{21}$ Ibn-e-Hazm, Ali bin Ahmad, Al-Ahkam fi Usool-il-Ahkam (Cairo, Dar-ul-Hadith, 1404AH) 2/213

22 Tahir Aljazairi, Toujeeh-un-Nazar Ila Usool-il-Asr (Halb, Al-Islamia Publications, $1^{\text {st }}$ ed. 1995)763/2

${ }^{23}$ Ibn-us-Salah, Muqaddimah Ibn-us-Salah, p.214, Ibn-e-Hazm, Al-Ahkam fi Usool-il-Ahkam, 213/2, Asmdi, Al-Ahkam, 146/2, Ghazali, Al-Mustasfa min Ilm-ul-Usool, 168/1

${ }^{24}$ Suyuti, Tadreeb-ur-Rawai fi Sharah Taqreeb-un-Nawawi, 95/2

${ }^{25}$ Ibid

26 Abd-ul-Ali, Muhammad bin Nizam-ud-Din, Fawateh-ur-Rahmut Bi-Sharh Musallim-us-Suboot (Egypt, Matbaa Ameeriah, $1^{\text {st }}$ ed. 1324AH) 166/2

27 Ashraf Khalifah Abd-ul-Mun'im, Qazaya Hadithah (Cairo, Maktabah Aulad Al-Sheikh litturath, 2004) p.455. He collected all the conditions in his book.

${ }^{28}$ Tahir Aljazairi, Toujeeh-un-Nazar Ila Usool-il-Asr, 673-691/2. (Please consult these pages)

${ }^{29}$ Ibn-e-Rajab, Sharah Ilal Al-Tirmidi, 433/1

${ }^{30}$ Abd-ul-Ali, Fawateh-ur-Rahmut Bi-Sharh Musallim-us-Suboot, 167/2

${ }^{31}$ Tahir Aljazairi, Toujeeh-un-Nazar Ila Usool-il-Asr, 673-691/2

${ }^{32}$ Muhammad bin Abu Shahba, Dr, Difaa an Al-Sunnah wa radd Shubha Al-Mustasjhriqeen wal Kitab Al-Muasareen (Cairo, Matba Al-Azhar, 1991)p.34

${ }^{33}$ Ibn-e-Kathir, Ismail bin Umar bin Kathir, Al-Ba 'is Al-Hathith fi Ikhtisar Uloom-ul-Hadith,p.120

${ }^{34}$ Ibn-Us-Salah, Muqaddimah Ibn-Us-Salah, p.214

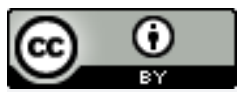

This work is licensed under a Creative Commons Attribution 4.0 International License. 